\title{
Formation Conditions of Hydrocarbon Systems on the Sakhalin Shelf of the Sea of Okhotsk Based on the Geochemical Studies and Modeling
}

\author{
V. YU. KERIMOV, G. N. GORDADZE, R. N. MUSTAEV and A. V. BONDAREV \\ Gubkin Russian State University of Oil and Gas (National Research University) \\ 65 Leninsky Prospekt, Moscow, 119991, Russian Federation. \\ ${ }^{\star}$ Corresponding author E-mail: r.mustaev@mail.ru
}

http://dx.doi.org/10.13005/ojc/340243

(Received: August 30, 2017; Accepted: January 01, 2018)

\begin{abstract}
The article is a study of the conditions and distribution patterns of generation and accumulation hydrocarbon systems (GAHS) on the Sakhalin shelf of the sea of Okhotsk. A complex of geochemical studies was conducted for the evaluation of oil and gas source rocks generative capabilities and for the study of the organic matter geochemical parameters. The study included the determination of total organic carbon (TOC) in rocks, pyrolysis by Rock-Eval method, parameters (S1, S2, Tmax, HI, PI); bitumoid extraction from rock with subsequent determination of its group composition. Analysis of oil geochemical parameters by hydrocarbons-biomarkers for the purpose of determination genetic unity and maturity level of oil and gas source sequences was conducted. Using the method of capillary gas-liquid chromatography (GZhC), the analysis of $\mathrm{n}$-alkanes and isoprenanes in paraffin-cycloparaffin (PCP) oil fractions was conducted. Method of chromato-mass spectrometry (ChMS) was utilized for a study of high-molecular hydrocarbons -biomarkers (steranes and terpanes). It was implemented using computer data processing under SIM regime with the recording ions $\mathrm{m} / \mathrm{z} 217,218$ for steranes and diasteranes, $\mathrm{m} / \mathrm{z} 191,177$ for terpanes. The separation of hydrocarbon organic matter was conducted in a capillary column with silicone phase HP-1ms. Chromatographing was implemented under temperature linear programming regime between 70 and $290^{\circ} \mathrm{C}$ at the rate of temperature increase $4 \mathrm{o} /$ minutes. The carrier gas was helium. The study of geochemical parameters in the Paleogene-Neogene sediment complex indicates a sufficiently high corg content and its concentration increases down the section. Organic matter type in the sedimentary section often changes from humic to humic-sapropelic, the dominating type is humic (III). GAHS, elements and processes of these natural systems were modeled for the study of the formation environment and distribution patterns of generative-accumulative hydrocarbon systems and $\mathrm{HC}$ generation foci and their energy resources on the Sakhalin shelf in the Sea of Okhotsk utilizing techniques of basin modeling and Petro Mod (Schlumberger) software. Based on modeling results, 6 independent generation foci of oil and gas were identified on the Sakhalin shelf. Each of them could have independently generated hydrocarbon fluids for saturating nearby traps.
\end{abstract}

Keywords: Geochemical research, Pyrolysis, Generation, Hydrocarbons-biomarkers, Organic matter, Hydrocarbon systems, The Sea of Okhotsk, Modeling. 


\section{INTRODUCTION}

Nine fields have been discovered on the Sakhalin shelf. Five of those are oil-gas-condensate, one gas-condensate, two gas and one gas-oil fields (Fig. 1). The Lunsk Field in its gas and condensate reserves and the Piltun-Astokh and Arkutun-Dagi field in its oil reserves are classified as large. Oil and gas accumulations have been discovered within the stratigraphic interval of Oligocene through Pliocene, however, practically all appraised reserves are concentrated in the Miocene sediments: Dagi, Okobykay horizons (Lower-Middle Miocene) and Lower Nutov subhorizon (Upper Miocene) ${ }^{1}$. The major oil-gas producing complexes on the Sakhalin shelf are the Okobykay-Lower Nutov and Uyni-Dagi; a substantial potential is associated with fractured reservoirs of the Dayekhuriye complex ${ }^{2-3}$. These complexes include three types of natural reservoir: sheet-type, massive-sheet-type and lensoid.

The generative-accumulative hydrocarbon systems (GAHS) include all geological elements and processes (generation, migration and accumulation of the hydrocarbon organic matter and $\mathrm{HC}$ generation foci) providing for the existance of $\mathrm{HC}$ accumulations. For the study of the GAHS formation environment on the Sakhalin shelf in the Sea of Okhotsk were conducted geochemical studies and modeling of hydrocarbon systems. As a result, several GAHS were identified with autonomous $\mathrm{HC}$ generation foci.

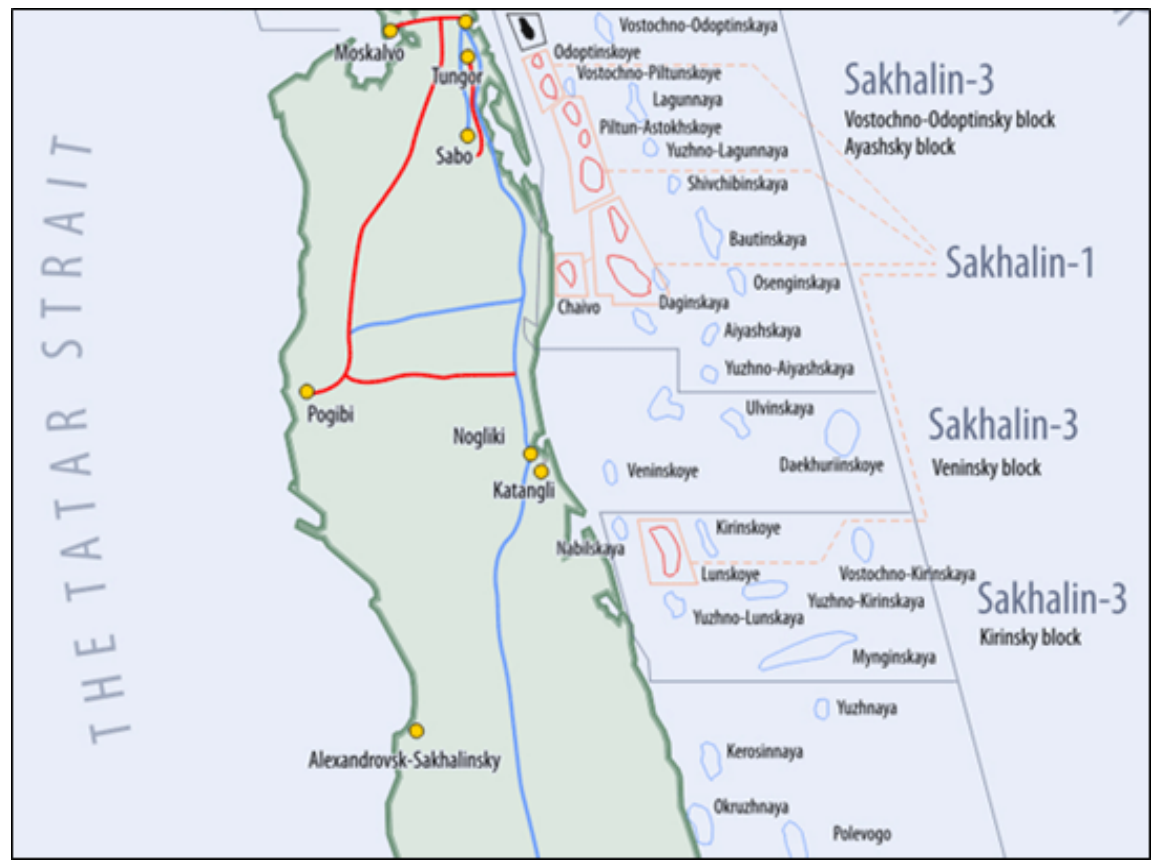

Fig. 1. Schematic map of the license areas and hydrocarbon fields on the Sakhalin shelf

\section{MATERIALS AND METHODS}

A complex of geochemical studies was conducted for the evaluating the generative capacity of the oil and gas source rocks and a review of the organic matter geochemical parameters. It included the determination of the organic carbon content $\left(\mathrm{C}_{\text {org }}\right)$ in rocks; pyrolysis of the dispersed organic matter Rock-Eval express method, attributes $\left(\mathrm{S}_{1}, \mathrm{~S}_{2}, \mathrm{~T}_{\max }\right.$, $\mathrm{HI}, \mathrm{PI})$; bitumoid extraction from rocks with subsequent determination of its group composition, etc ${ }^{4-5}$.
Analysis of oil geochemical parameters was conducted in hydrocarbons-biomarkers for the purpose of establishing the genetic unity and determining the maturity level of oil and gas source sequences.

The method of capillary gas-liquid chromatography (GLCh) was used to conduct an analysis of $n$-alkanes and isoprenanes in oil paraffincycloparaffine (PCP) fractions with the utilization of a quartz capillary column, $25 \mathrm{~m}$ long and $0.25 \mathrm{~mm}$ 
in diameter with grafted phase NR-16. The carrier gas was hydrogen, the detector was flame ionization. Chromatographic analysis was performed under the regime of linear temperature programming from 80 to $320^{\circ} \mathrm{C}$ at a rate of the temperature rise $4 \%$ minutes.

The method of chromate-mass spectrometry (ChMS) and Agilent 6890N/5975C equipment were used to conduct the study of high-molecular hydrocarbons-biomarkers (steranes and terpanes). The study was implemented using computer data processing under the SIM regime with the recording ions $\mathrm{m} / \mathrm{z} 217,218$ for steranes and diasteranes, $\mathrm{m} / \mathrm{z} 191,177$ for terpanes. The separation of hydrocarbon organic matter was performed in a capillary column with the silicone phase NR-1 ms. Chromatographing was implemented under the temperature linear programing regime between 70 and $290^{\circ} \mathrm{C}$ at a rate of the temperature increase $4 \%$ minutes. The carrier gas was helium. All spectra were recorded at the ionization energy $70 \mathrm{ev}$, temperature in the ionization cell $250^{\circ} \mathrm{C}$. The record of the spectra was conducted under a regime of chromatogram computer reconstruction based on ion fragments typical for different $\mathrm{HC}$ groups.

For studying the formation environment and distribution pattern of the generativecumulative hydrocarbon systems and generation foci of hydrocarbons and their energy resources on the Sakhalin shelf in the Sea of Okhotsk have been modeled GAHS, elements and processes of these natural systems utilizing the technique of basin modeling and PetroMod package

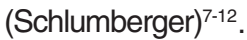

\section{Study results}

The studied Sakhalin shelf sediments have quite high Corg content with its concentrations increasing down the section. The richest varieties are found in the Upper Dagi sub-horizon. Organic matter type in the sediment section often varies between humic and humic-sapropelic. The dominant type is humic (III). A great amount of the sapropelic components had been identified in the organic matter of the Okobykay and Lower Nutov sub-horizon sediments in the South-Kirin well (type I-II-III - humic-sapropelic organic matter with a great fraction of the sapropelic component).

Based on a set of analytical data, oil and gas source sediments have been identified in the Upper Dagi sub-horizon, Okobykay Formation and Lower Nutov sub-horizon. The extent of the source rock maturity ( $\mathrm{T}$ max) varies within a narrow range of $420-430{ }^{\circ} \mathrm{C}$ despite a significant depth range of the sediments $(600-3,600 \mathrm{~m})$. A weak T max value increase trend down the section was recorded. Overall, all studied sediments are at the end of protokatogenesis (PKZ) and in the beginning of the oil window (Mк1). A trend of improving sediments' oil generative capabilities eastward from the Kirin and Myngi structures toward the South-Kirin structure has been recorded. Most favorable conditions in terms of oil and gas occurrences belong to Kirin structure. Within its limits, most of the studied section from the Dagi to the Okobykay sequences may generate Hydrocarbon's.

The primary perspective target are the Dagi and Okobykay horizons. The HC amount generated by NMT of the Upper Dagi sub-horizon and Okobykay horizon, due to a relatively low maturity and/or their nonuniform composition is apparently insufficient for the formation of $\mathrm{HC}$ accumulations within these sequences. Additional sources for the formation of $\mathrm{HC}$ fluid accumulations in the reservoirs of the Dagi and Okobykay horizons in the Kirin area are the Lukamin and Dayekhuriye source rock encountered in the Chayvo and Pogranichny troughs. The Machigar horizon source rock has elevated content of humic organic matter (Copr up to 1.0\%). The Dayekhuriye horizon organic matter includes large amounts of the sapropelic component. However, in view of a high degree of their transformation, they deliver mostly gas HC. Forecast accumulations in the Dagi, Okobykay and Lower Nutov reservoirs may have gas and gas-condensate composition. The oil component in the accumulations will be increasing eastward toward the Sea of Okhotsk. 


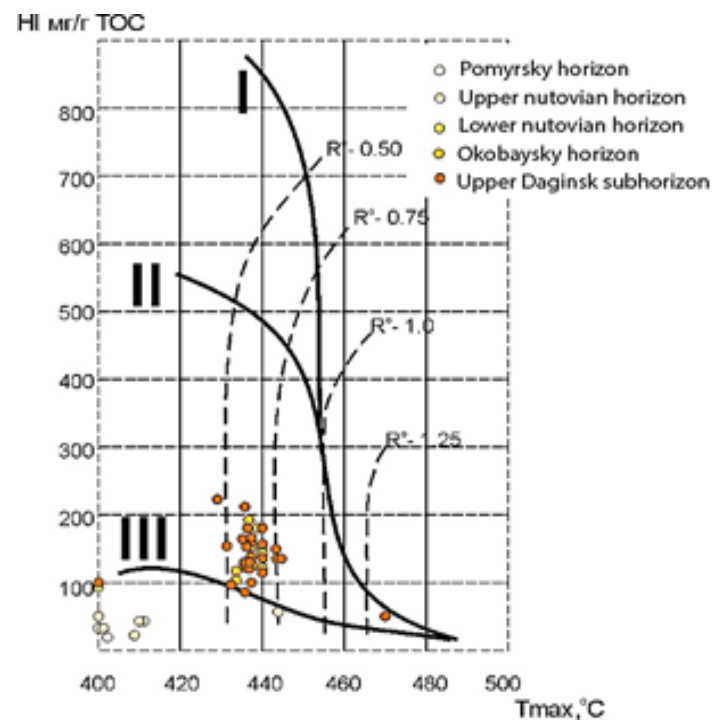

(a)

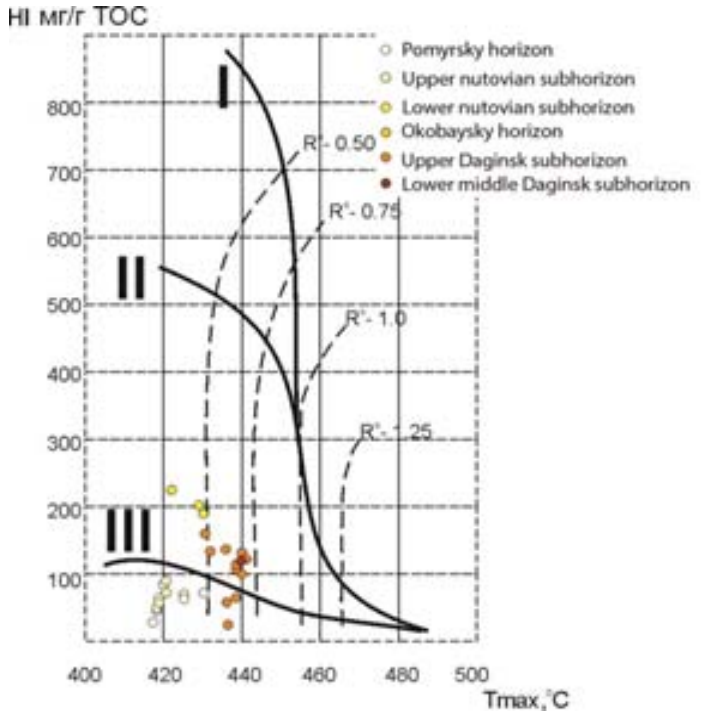

(b)

Fig. 2. Van Krevelen diagrams for samples from wells: $a$ - Kirinskaya-3 and b - South-Kirin -1

For the kerogen study were analyzed correlations of the hydrogen index in sedimentary rocks vs. T max (Fig. 2). Major kerogen parameters of the oil source sequences are included in Table 1. Geochemical characteristics of Sakhalin oil by terpens in Table 2 .

Table 1: The main characteristics of the kerogen of oil-bearing strata

\begin{tabular}{lccccc}
\hline Source rock & Age & TOC, \% & $\begin{array}{c}\mathrm{HI}, \mathrm{mg} \mathrm{HC} / \\
\text { g TOC }\end{array}$ & $\begin{array}{c}\text { Type of } \\
\text { organic matter }\end{array}$ & $\Sigma$ thickness, m \\
\hline Lower Nutovian subhorizon & $\mathrm{N} 1$ & 1,0 & 250 & II-III & 350 \\
Okobykayskiy horizon & $\mathrm{N} 1$ & 1,0 & 150 & II-III & 220 \\
Upper Daginsk subhorizon & $\mathrm{N} 1$ & 1,5 & 150 & III & 90 \\
\hline
\end{tabular}

Table 2: Geochemical characteristics of Sakhalin oil by terpenes

\begin{tabular}{|c|c|c|c|c|c|c|c|c|}
\hline Object of study & $\begin{array}{l}\mathrm{Ts} / \\
\mathrm{Tm}\end{array}$ & $\begin{array}{c}\mathrm{Ts} / \\
\mathrm{Ts}+\mathrm{Tm}\end{array}$ & $\begin{array}{l}\mathrm{G}_{29} / \\
\mathrm{G}_{30}\end{array}$ & $\begin{array}{l}\mathrm{M}_{30} / \\
\mathrm{G}_{30}\end{array}$ & $\operatorname{neoG}_{29} /$ & $\begin{array}{l}27: 29: \\
30: 31\end{array}$ & $\begin{array}{l}\text { Oleanan/ } \\
\mathrm{G}_{30}\end{array}$ & $\begin{array}{r}\text { Three/ } \\
\text { penta }\end{array}$ \\
\hline $\begin{array}{l}\text { South-Kirin Field, well. } 3 \text {, } \\
\text { 2864-2872 m (Early-Middle Miocene, } \\
\text { Upper Daginskian horizon, } \mathrm{N}_{1}{ }^{1-2} \mathrm{dg}_{3} \text { ) }\end{array}$ & 0,50 & 0,30 & 0,50 & 0,17 & 0,16 & $10: 21: 43: 26$ & 0,22 & 0,20 \\
\hline $\begin{array}{l}\text { Piltun-Astokhskoye (late Miocene, } \\
\text { Lower Nutovian subhorizon, } \mathrm{N}_{1}^{2-3} \mathrm{nt}_{1} \text { ) }\end{array}$ & 1,0 & 0,5 & 0,46 & 0,15 & 0,17 & $14: 20: 43: 23$ & 0,18 & 0,19 \\
\hline
\end{tabular}

The study of organic matter geochemical parameters showed that genetic potential of sediments overall varies between satisfactory and very high. High and very high potential is typical of Dagi, Okobykay and Lower Nutov horizons (Figure 3).
The studies of crude oils were conducted in the Piltun - Astokh field (the age was determined as Early Miocene of the Lower Nutov horizon N12-3nt1) and in the South Kirin field, well South-Kirin-3 (interval 2,864-2,872 m), the age was 
determined as Early-Middle Miocene (Upper Dagi horizon, N11-2dg3). The studies produced the following results. The studied crude oils are near-shore marine; the crude of the Piltun-Astokh field was generated in carbonate-clayey sequences and the crude of the South Kirin field was generated by carbonate sequences. The crude oils in the Piltun - Astokh field from the Lower Nutov horizon N12-3nt1 (Late Miocene) and South Kirin field (the Upper Dagi horizon N11-2dg3, Lower and Middle Miocene) were most likely generated by the same age rocks. The crude oils include oleananes, which are usually found in lake deposits or marine clays and were derived from various onland precursors, especially angiosperms, which are produced by resins. Their occurrence in marine environments was most likely caused by the transport from onland sources.

For establishing a genetic unity and the determination of the maturity level for oil and gas source sequences, analysis was conducted of oil geochemical parameters using hydrocarbons biomarkers ${ }^{13-17}$. The following conclusions have been made.

The n-alkanes and isoprenanes. The value of the genetic parameter-the ratio of 2,6,10,14tetramethilpentadekane to 2,6,10,14tetramethilhexadecane (pristan/phytane) in the samples of both oil studies are greater than 1 (1.56 and 1.28 , respectively, for the Piltun-Astoh and South-Kirin fields). This indicates that the deposition was occurring under a sub-reducing environment. In both oils, relative contents of $\mathrm{n}$-heptadecane and n-octadecane are close to the relative content of pristane and phytane, respectively. This indicates that these oils have been subjected to biodegradation and/or are poorly mature. In the transformed non-biodegraded oils, relative concentrations of $n-C_{17}$ and $n-C_{18}$ are usually always higher than relative pristane and phytane concentrations. (It is known that n-alkanes are preferred biodegradation targets and that the kerogen with a greater difficulty releases $n$-alkanes compared to isoprenanes). Most likely, the studied oils have been subjected to a weak biodegradation as in both oils are observed rather high concentrations of light $n$-alkanes, which is typical of mature oils.

The following fact is interesting: despite the fact that the oil in the South Kirin field is currently at the temperature $125^{\circ} \mathrm{C}$ (oil biodegradation does not occur at the temperature above $80^{\circ} \mathrm{C}$ ), the extent of its biodegradation is higher than in the oil of Piltun-Astoh Field. This conclusion is also supported by bimodal $n$-alcane distribution in oils of Piltun-Astoh Field: it is known that at initial biodegradation stages bacteria consume more low-molecular n-alkanes $\mathrm{C}_{12}-\mathrm{C}_{18}$ (Figure. 4 and 5a).
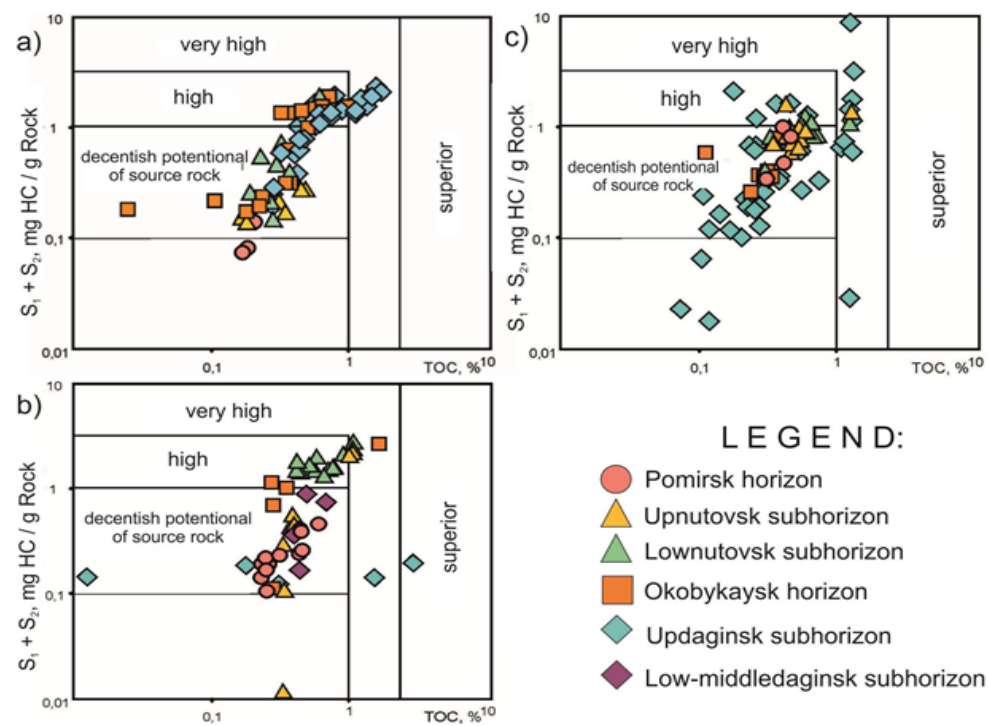

LEGEN D:

Pomirsk horizon

Upnutovsk subhorizon

$\triangle$ Lownutovsk subhorizon

Okobykaysk horizon

Updaginsk subhorizon

Low-middledaginsk subhorizon

Fig. 3. Genetic potential of sediments from wells: À. Kirin-3; B. SouthKirin-1; C. Myngin-1 (at the MSU materials) 


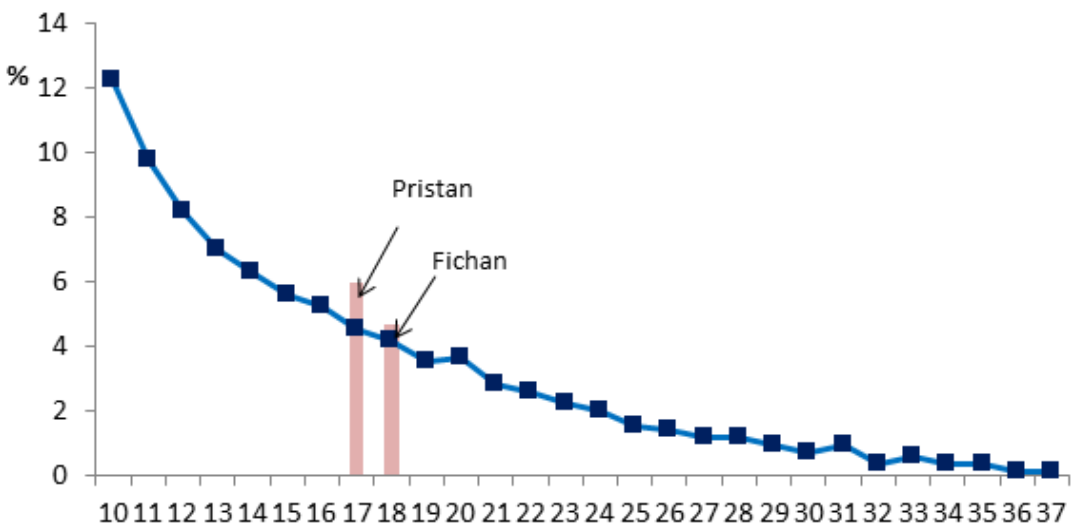

The number of " $\mathrm{C}$ " atoms in n-alkane

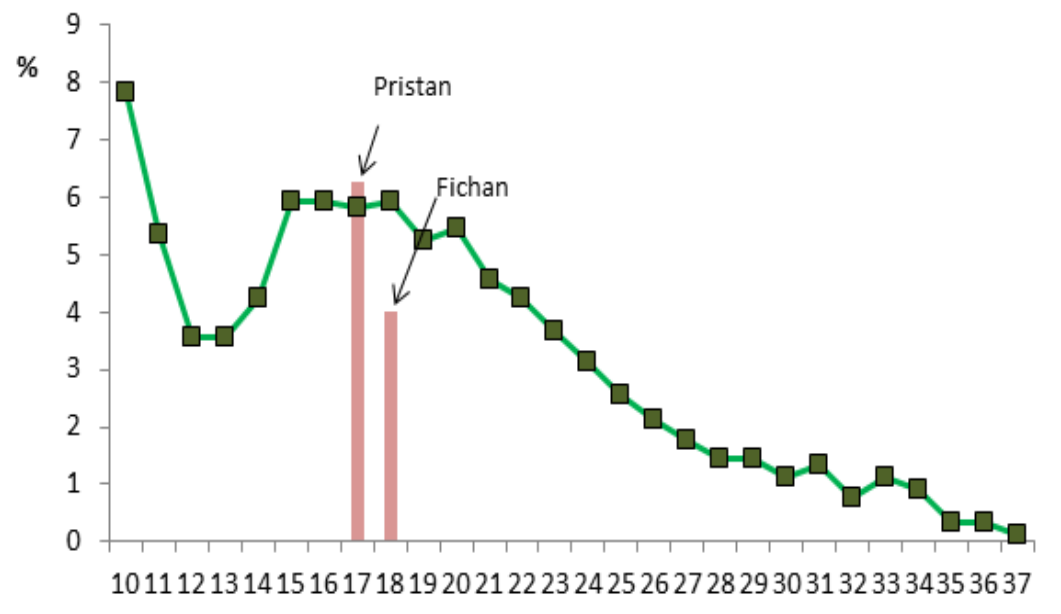

The number of " $\mathrm{C}$ " atoms in n-alkane

Fig. 4. The n-alkane and isoprenane distribution in oils: À - South-Kirin Field, B - Piltun-Astoh Field

\section{Steranes}

Based on the regular steranes $\mathrm{C}_{27}-\mathrm{C}_{29}$ distribution. (Fig. 5. b), a conclusion may be made that the studied crudes are near-shore - marine, whose maturity coefficients $\kappa^{1}$ and $\kappa^{2}{ }_{3 p}$ almost reached eqiuilibrium. The oil in the Piltun-Astoh Field was generated in carbonate-clay sequences (the dia/reg value is 0.39 ) and the oil in the SouthKirin Field was generated by carbonate sequences (the dia/reg value is 0.13 ). Despite the ratio value of regular steranes $\mathrm{C}_{28} / \mathrm{C}_{29}$ in the oil of the Piltun-Astoh Field is greater than in the South-Kirin Field oil (1.41 against 1.24), both oils, most likely, have been generated in same age rocks. According to Grandham, they have been generated in Paleogene rocks. The difference in these ratios may have been caused by a different input of the continental organic matter (in the continental organic matter, the relative content of a regular sterane $\mathrm{C}_{29}$ is much higher than the content of sterane $\mathrm{C}_{28}$ ).

\section{Terpanes}

A conclusion may be made from terpane distribution (Fig. 5b, Table 2) that in both crudes the oleanan is present. Oleanans are found in the lacustrine strata or marine shales in Indonesia and are mostly associated with sediments of Tertiary and Late Cretaceous age. It is suggested that oleanans emerged from various onland precursors, especially angiosperms, which are produced by resins. Their presence in marine environments is probably caused in most cases by a transport from onland sources. Some scientists believe that the angiosperms emerged only in Late Cretaceous, and that is why the oleanans are absent from the Lower Cretaceous and older sediments. 

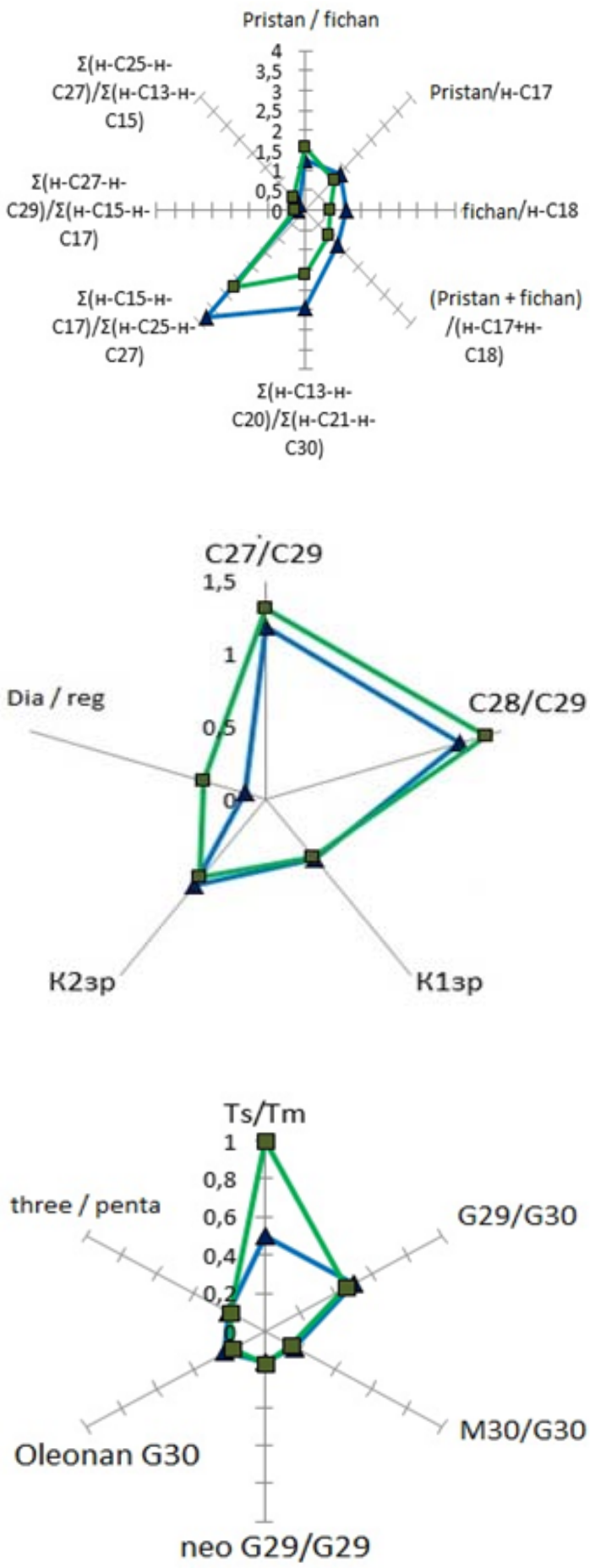

\section{\pm South-Kirin Field $\quad \rightarrow$ Piltun Astokhsk Field}

Fig. 5. Geochemical parameters of the Sakhalin shelf oils: À - based on n-alkanes and

isoprenanes, B - based on steranes, $\mathrm{C}$ - based on terpanes
The Ts/Tm ratio value $22,27,29$ trisnormethylgolanes is low, at that, this value in the Piltun-Astoh oil (1.0) is double of that in SouthKirin oil (0.5). Perhaps this difference may be explained by the facies particulars. Possibly, in the case of the Piltun-Astoh Field oil, the clay sequence with its catalytic activity played some role. At the same time it is necessary to note that the ratio value adiantane/hopane in both crudes is equally low ( 0.46 and 0.50 ), which is typical of oils generated in clay sequences. For oils generated in carbonate sequences the relative adiantane content is greater than the relative hopane content. Some contradiction is observed here.

Using the derived results and earlier published data (Gretskoy Å.V., Popovich T. À., etc.), a triple diagram was constructed of regular steranes distribution for a number of oil and gas fields of the study area (Figure 6).

Analysis of the triple diagram showed that the entire massif of studied oils falls into two genotypes. The studied samples belong with the first one, it has approximately similar values of steranes $\mathrm{C}_{27}: \mathrm{C}_{28}: \mathrm{C}_{29}$ content with domination of $\mathrm{C}_{27}$ $\left(\mathrm{C}_{27} / \mathrm{C}_{29}\right.$ ratios vary within the range of 1.0 to 2.3 , $\mathrm{C}_{28} / \mathrm{C}_{29}-0.8$ to 1.3 ) and quite low values of $\Sigma \mathrm{CG} /$ $\Sigma \mathrm{CP}$ between 0.2 and 1.1 and $\mathrm{P} / \mathrm{Ph}$ between 1.3 and 1.8. The specific biomarker oleanan is present in insignificant amounts. Hydrocarbon composition indicates that the oil generation source was organic matter of a mixed type with prevalent sapropel components.

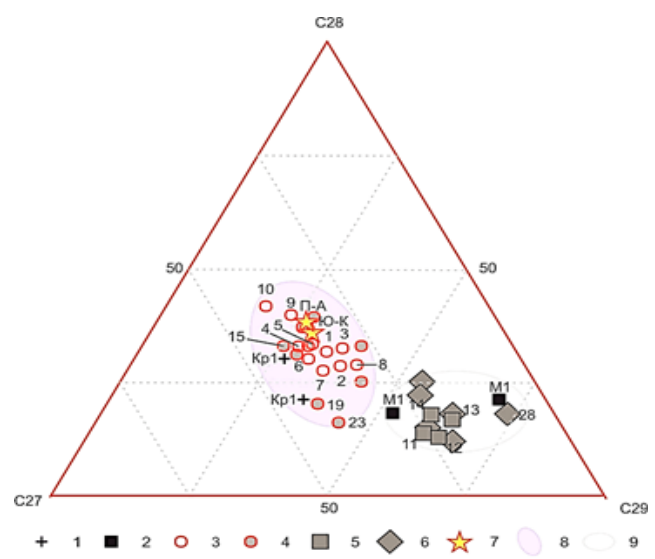

Fig. 6. Triangle diagram of regular steranes C27/C28/C29 distribution in oils, gas-condensates and chloroform bitumoids of the Sakhalin rocks 
1 - organic matter from an Oligocene silica clay; 2 - organic matter from an Eocene coaly argillite; 3-4 oils and gas-condensates from a sapropel type matter (3 - data after (Popovich, 1998), 4 - data after (Gretskaya, 2012)); 5-6 - Oils and gas-condensates from a coaly type matter (5 - data after (Popovich, 1998), 4 - data after (Gretskaya, 2012)); 7 - oils based on this study; 8 - Oils and gas-condensate composition field from a sapropel type matter; 9 - Oils and gas-condensate composition field from a coaly type matter.

Kr1 - Krestovskaya-1 well, M1 - Malkinskaya1 well, P-A - Piltun-Astoh Field, S-K- South-Kirin Field.

Genotype I includes oils in the fields associated with heterochronous NGK: the Dayekhuriye (Okruzhnoye Field), Dagi (PiltunAstoh Field), Okobykay-Nutov, positioned in the northeastern Sakhalin and the adjacent shelf.

Genotype II includes oils with dominating n-sterane $\mathrm{C}_{29}$ (ratios $\mathrm{C}_{27} / \mathrm{C}_{29}$ and $\mathrm{C}_{28} / \mathrm{C}_{29}$ vary within a narrow range of 0.1 to 0.4 ) and higher values of ratios $\Sigma C G / \Sigma C P$ greater than 1.2 , and $P / P h$ of $1.5-2.7$ and greater. The content of a specific biomarker oleanan is significantly increased. The oil hydrocarbon composition indicates mostly humic type of original organic matter with insignificant fraction of marine, possibly near-shore marine and lagoon origin sapropel components (intermediate between humic-sapropelic and sapropel-humic). The oils in the fields of mostly Dagi-Uynin NGK and some oils of the Nutov-Okobykay NGK in the western and central parts of North Sakhalin belong with type II.

$\mathrm{HC}$ parameters of the identified oil and condensate genotypes in the northeastern part of the Sakhalin shelf indicate that the source for their formation was original organic matter of various facies-genetic type. Type I oils have been generated by the original organic matter with a large fraction of the sapropel component; and type II, with a large fraction of the humic component.

The conducted study of the geodynamic evolution for the Sakhalin shelf depositional basins enabled the identification of 25 GAHS. 17 GAHS were identified within the lower structural stage (Fig. 7a) and 8 GAHS, in the Upper structural stage (Fig. 7b). They differ in their evolution features, size, depth of generation foci (often several of them), type of oil and gas source rocks, etc. Based on the created geodynamic model of the Sakhalin shelf, numerical modeling of generative-cumulative hydrocarbon systems was performed, GAHS were mapped and profiles (GAHS) were constructed. Within each GAHS are identified autonomous generation foci (Figure 10).

Most generation foci GAHS are represented by coal-bearing oil and gas source rocks. Within the system of the North-Sakhalin, Deryugin, Pogranichny and South-Pogranichny basins also siliceous (diatomite) oil and gas source rocks are common. The organic matter maturity at the current evolution stage of the system within the generation foci varies between the catagenesis level between $\mathrm{M \kappa}_{1}$ and $\mathrm{M \kappa}_{5}$ and higher. Most mature oil and gas source rocks are anticipated in the NorthSakhalin, Deryugin and Pogranichny basins where within GAHS (Northern and Central Paleogene of the North-Sakhalin trough, Pogranichny Paleogene, Central and West-Deryugin Paleogene) the oil and gas source rocks practically completely implemented (exhausted) their generative potential.

The oil and gas source rocks potential implementation degree in the northwestern GAHS of the North-Sakhalin trough and in the West-Sakhalin GAHS does not exceed 50\% Small GAHS of the Deryugin, North-Deryugin, East-Deryugin and also South-Pogranichny basins have only just begun implementing their potential-TR index there varies between single percentage points and a few dozen percent. Modeling results show that within the Sakhalin shelf the largest hydrocarbon generation foci are positioned within the Deryugin, Pogranichny, West-Sakhalin and North-Sakhalin basins (GAHS: West-Sakhalin Paleogene, Central Paleogene of the North-Sakhalin basin, Central and West-Deryugin Paleogene, Pogranichny Paleogene).

The hydrocarbon generation and emigration processes began first (in Eocene) within Central Paleogene GAHS of the North-Sakhalin basin and already by the end of Oligocene the system reached the critical state. This was caused by the organic matter kerogen type (II) of the 
diatomaceous source rock and high deposition rate in the basin. In the GAHS of the West-Sakhalin and Pogranichny basins (kerogen type III, coaliferous oil and gas source rocks) hydrocarbon generation and migration began later, in the second half of
Oligocene. Most intensely these processes were going on up to the middle of miocene, and the critical moment of hydrocarbon systems occurred in the middle of Miocene.

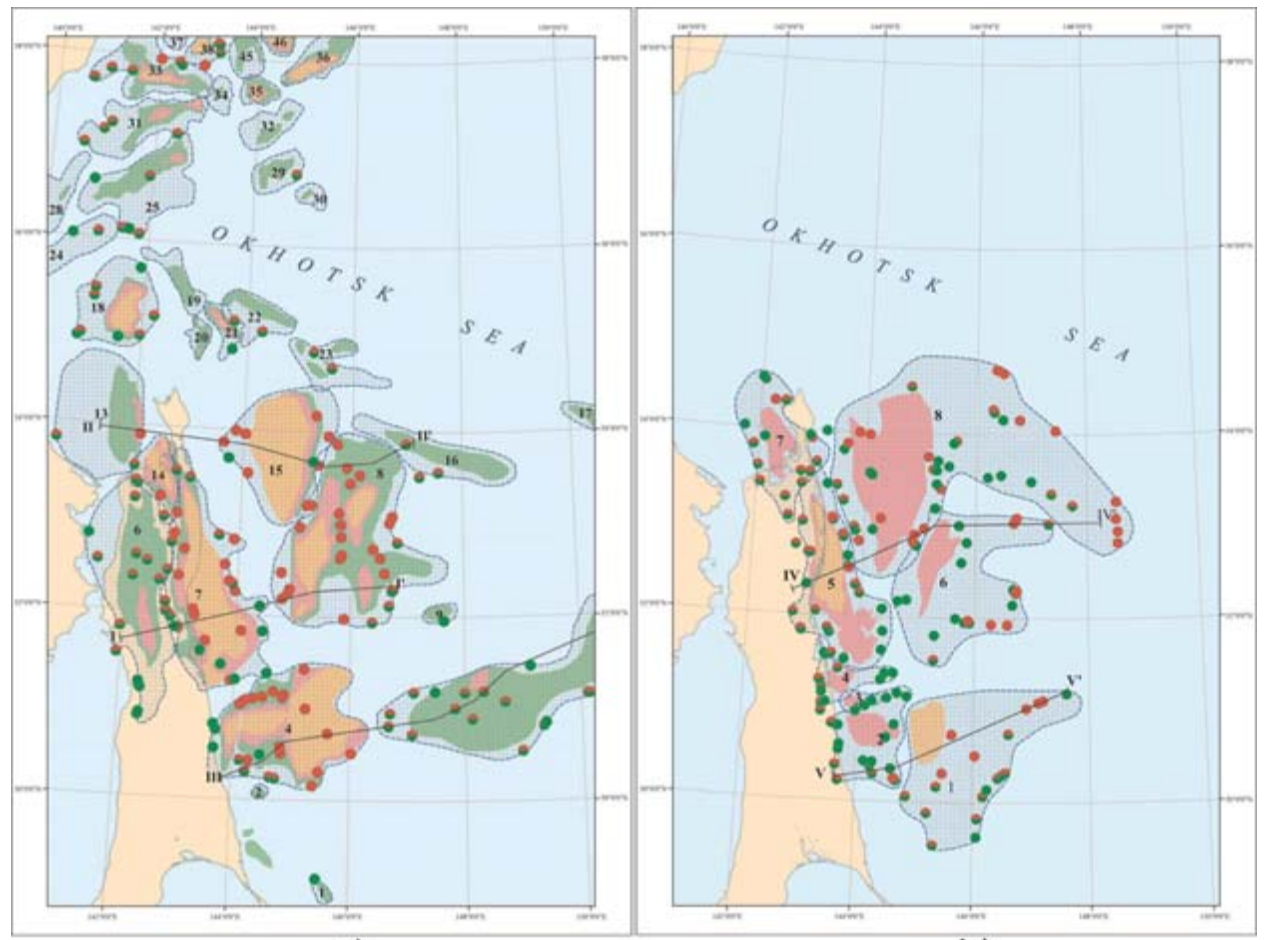

a)

b)

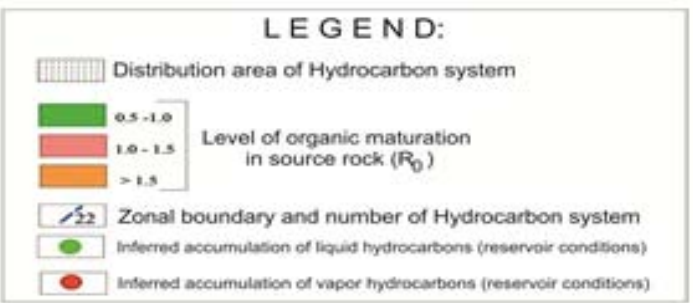

Fig. 7. Maps GAHS, a - lower structural floor; b- upper structural floor

The processes of hydrocarbon generation and emigration in the Central-Deryugin GAHS with coaliferous oil and gas source rocks began in Early Oligocene but due to low sediment accumulation rate in the basin and low subsidence rate the intensity of these processes drastically increased only by the middle of miocene. In the West-Deryugin GAHS and in small hydrocarbon systems on the Sakhalin shelf the beginning of hydrocarbon generation and migration occurred in the middle of
Miocene and by present time the critical moment had not been reached in many systems.

The composition of GAHS generated hydrocarbons on the Sakhalin shelf is dominated (on average about $70 \%$ ) by gas hydrocarbons. This is due to the kerogen type most common for the coaliferous oil and gas source rocks. Only within the Central Paleogene GAHS in the North-Sakhalin basin where the diatomaceous oil and gas source 
rocks are found the amount of gas hydrocarbons is less than half. In the West-Deryugin Paleogene GAHS with similar source rocks in the composition of the forecast accumulations prevail gas hydrocarbons, which is caused by the re-formation of hydrocarbon accumulations as a result of the basin subsidence and also of the processes of secondary cracking.

Oil and gas source rocks of upper structural floor (diatomaceous sediments containing type II kerogen) are found in the generation foci at substantial depths. This is the reason of a high maturity of their organic matter and the degree of generative potential implementation. All GAHS on the Sakhalin shelf, except for the West-Pogranichny Neogene, are typical in similar evolution features. The hydrocarbon generation began in the middle of Miocene and reached maximum by Pliocene. Appropriately, the critical moment corresponds with the current stage of the system evolution.

The hydrocarbon generation and emigration processes in the West-Pogranichny GAHS began earlier, at the end of Oligocene, and strengthened in the middle of Miocene. By the end of Miocene, GAHS overcame the critical moment. In the Neogene generated hydrocarbons in the GAHS' gas hydrocarbons are in subordinated amounts, their fraction does not exceed $20 \%$.

In all Sakhalin shelf Neogene hydrocarbon systems, except Central-Pogranichny, the processes of generation, migration and accumulation were continuously strengthening up to the present, following the increase in organic matter maturity. In the Central-Pogranichny Neogene GAHS since end Miocene a decline in hydrocarbon generation and emigration and the secondary cracking are observed. Overall, since the end Miocene the hydrocarbon accumulations form at a lower rate. Changes in the reservoir structural geometry caused changes in the migration paths, re-formation of traps, destruction of previously formed accumulations and loss of gas hydrocarbons. As a result, in the remaining accumulations, the ratio of liquid and gas hydrocarbons shifts in favor of liquids, despite the secondary cracking.

\section{DISCUSSION}

The study of qualitative and quantitative organic matter parameters and their variations in the siliceous rock section of the Cenozoic basins enabled the identification of certain pattern in the organic matter geochemistry of siliceous sequences. The major organic matter source in the Cenozoic siliceous sequences were diatomaceous algae with elevated contents of lipoid components. The second in significance organic matter supplier were bacteria. The formation of the organic matter oil-gas source rock potential was affected not so much by specific composition of the producers as by their ecology. Besides, the sedimentogenesis and diagenesis particulars define the variance in hetero-element organic matter composition of the sediments with the same producers. The elevated content of organic carbon in the studied siliceous rocks of the Northwestern Pacific Belt is a typical feature not of pure silicites but of their clayey varieties. Two major types of the siliceous-carbon deposition were identified: associated with upwelling zones and areal, associated with the edge portions of the ocean and marginal seas.

The areal deposition type is represented by clayey-diatomaceous and diatomaceous-clayey oozes with relatively elevated (up to $3.5 \%$ ) organic matter concentration. This sedimentation type is most common within the Sea of Okhotsk aquatorium. Its typical feature is a spotty development of siliceous sediments with the elevated organic matter content. Beside bioproductivity, important factors in the formation of sediments with high organic matter content were reducing depositional environment and quiescent hydrodynamic regime.

The activation energy distribution for the kerogen in the clayey interbeds of the Upper Dagi subhorizon and Lyukamin horizon was assumed similar to the activation energy distribution for the standard kerogen type III in clayey sediments of the Lower Nutov subhorizon, Okobykay, Dayekhuriye and 
Machigar horizons and also clayey-clastic deposits of the Upper Cretaceous complex-type II-III, depending on the organic matter accumulation environment.

For the determination of the oil window were utilized calculated values of the vitrinite reflectance based on $T_{\max }$, with screening out values due to low generative potential for the measurement accuracy. The geochemical study results enabled the creation of a 3D evolution model of hydrocarbon generation zones (Fig. 8, 9) in the potential oil and gas source rocks of the Sakhalin shelf clayey (clayey-siliceous) Dayekhuriye, coaly Middle Dagi and clayey Okobykay and Nutov horizons.
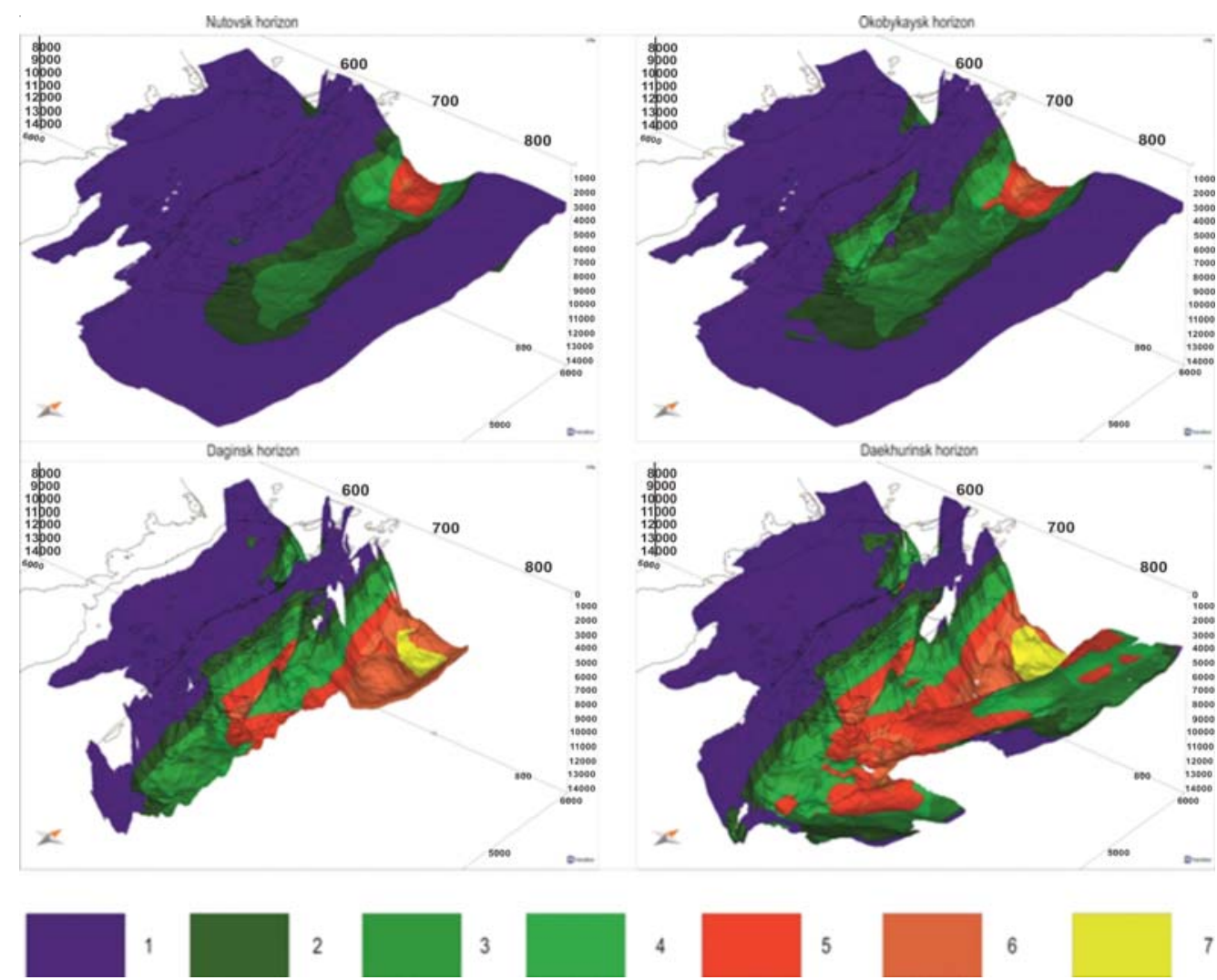

Fig. 8. 3D models of the hydrocarbon generation zones on the Sakhalin shelf. 1-7. Generation zones: 1. Immature zone (Ro $0-0.6 \%$ ); 2 . Zone of early oil (Ro 0.6-0.7\%); 3. Zone of main oil (Ro $0.7-1 \%)$; 4 . Zone of late oil and condensate (Ro 1-1.4\%); 5. Zone of wet gas (Ro 1.4-2\%); 6. Zone of dry gas (Ro 2-4\%); 7. Zone of no-hydrocarbon gas (Ro $>4 \%$ );

Clay (clayey-siliceous) Daehurin, coalbearing Middle Dagin and clayey Okobycay and Nutovsky horizons should be considered as potential oil and gas breeders. In accordance with this, for each of these horizons, the reflectivity of vitrinite (Ro,\%) was calculated (Figure 9).

As suggested by the results of geochemical studies ${ }^{18-23}$, the Nutovsky horizon is catagenically immature. In the depots of the Deryugin and Chayvinskaya depressions, the Piltura and Veninka synclinal zones, the Okobykai horizon entered the hydrocarbon generation zone. However, apparently, it happened relatively recently. This means that this horizon did not exert much influence on the distribution of hydrocarbon deposits in the area of the Prisakhalin shelf in question. 
A
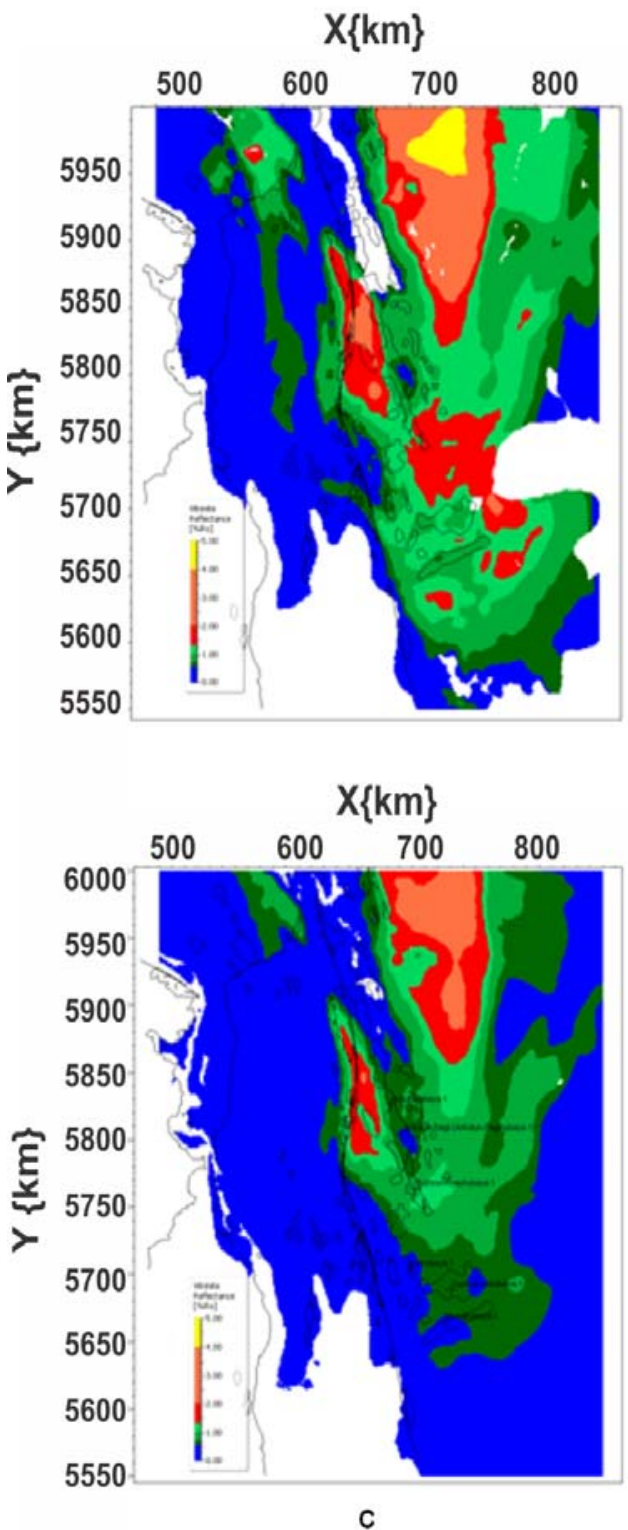
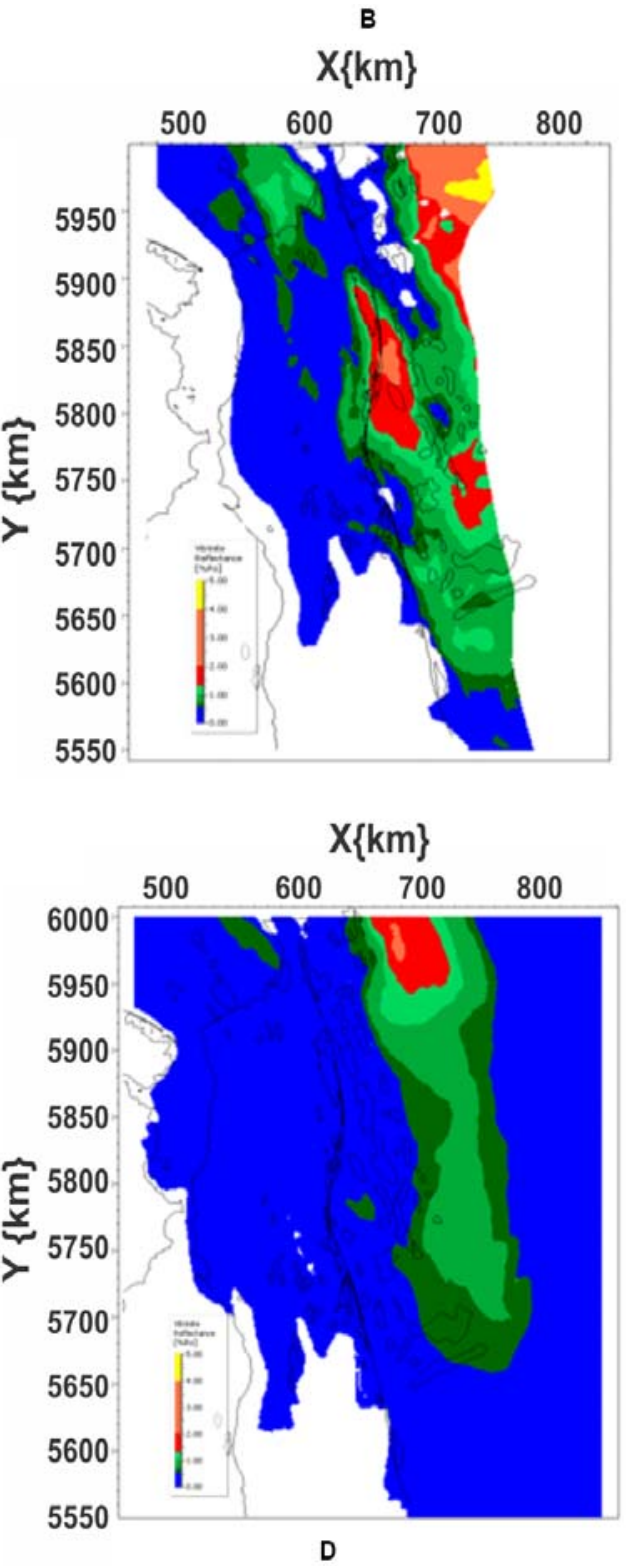

Fig. 9. Maps of distribution of vitrinite reflectivity and oil and gas production zones: a- in the Paleogene roofing zone; b - in the Daginian sediments; $c$ - in the Okobycay sediments; d - in the Nutian sediments

Based on modeling results ${ }^{24-26}$ six large (along with small) independent oil and gas generation foci were identified (Fig. 10) encompassing different stratigraphic ranges. Each of them could independently produce hydrocarbon fluids for the saturation of adjacent traps.

The Deryugin generation focus is localized in the Deryugin depression and is observed in all sediment cover horizons up to the Nutov with a gradual decrease in the focus area up the section. This focus is the assumed hydrocarbon source for filling up the structures: East Odoptu, Lozin, Shivchibin, Bautin and also the discovered fields Pela-leich and Khanguzin.

The Piltun-Chayvo generation focus is localized in the Piltun and Chayvo synclinal zones 
up to the Okobykay sediments. It is a most likely source of hydrocarbons for the fields Odoptu-Sea, Piltun-Astokh, Arkutun-Dagi and Chayvo.

The Venin generation focus is localized within the Venin synclinal zone up to the Dagi sediments and lower section of the Okobykay horizon. It is the hydrocarbon source for the fields: Venin, Lunsk, Kirin, South Kirin and structures Ayash, South Ayash, Ulvin and East Ulvin.

The Kirin generation focus is localized within the Myngin and Kirin synclinal zones up to the Dagi sediments. It is a secondary hydrocarbon source for the fields: Lunsk, Kirin, South Kirin and Myngin.

The North Pogranichny generation focus is localized within the Pogranichny synclinal zone up to the Dagi sediments. It is a secondary hydrocarbon source for the Myngin field.

The Astrakhanov generation focus is localized west of the Schmidt Peninsula within the Astrakhanov synclinal zone up to the Okobykay sediments. It is the hydrocarbon source for the Astrakhanov Field. This generation focus is of low interest for the purpose of oil and gas forecast on the Sakhalin shelf.

Thus, based on the study results maps of the oil and gas generation foci have been plotted (Fig. 10-à and -b). Localization of the generation foci enables joining of the discovered fields and potential traps in groups by the association with the hydrocarbon source. Individual fields and traps may be attributed simultaneously to several foci. This renders positive effect on their future potential.

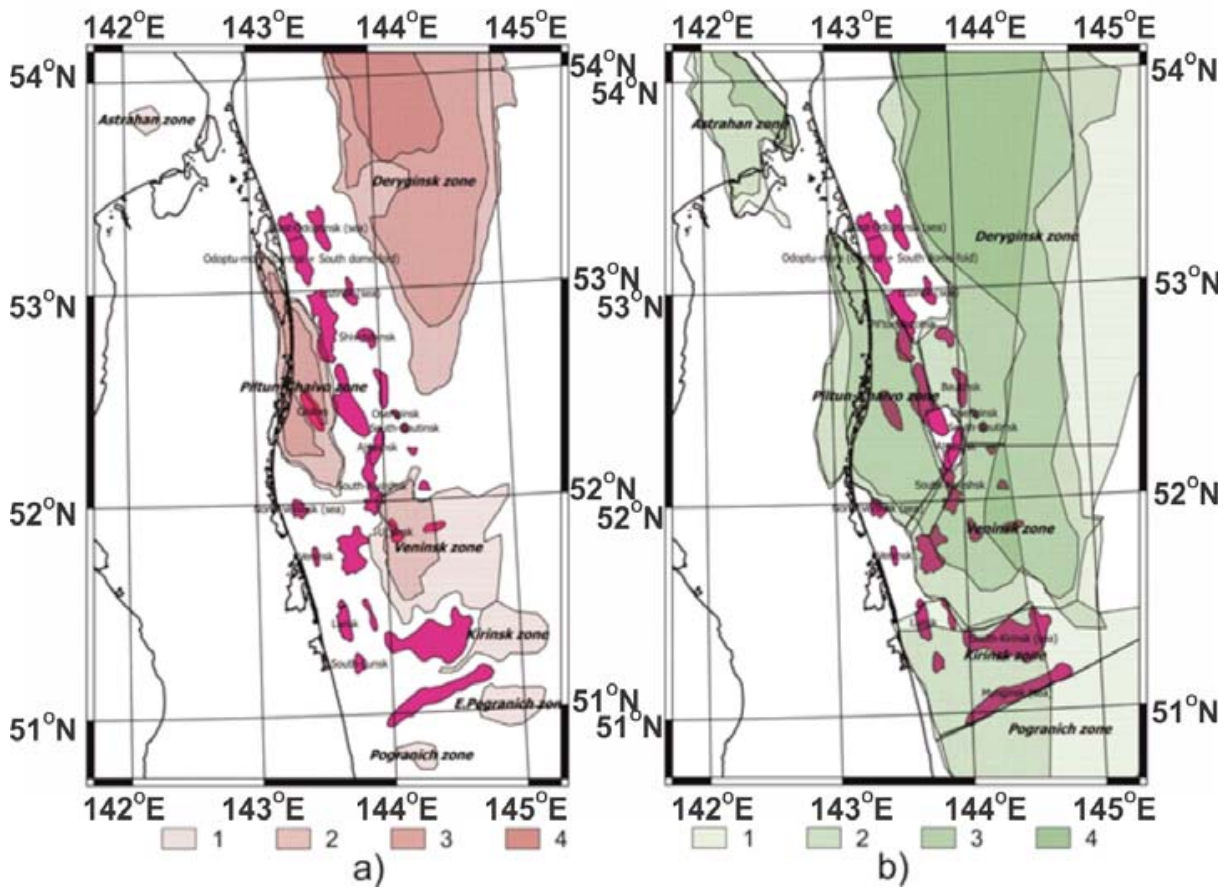

Fig. 10. A generation foci map based on modeling results: à) oil; b) gas;Symbols: 1. In the Dayekhuriye rocks; 2 . In the Dagi rocks; 3. In the Okobykay rocks; 4 . In the Nutov rcks;

\section{CONCLUSIONS}

The studied sediments have rather high content of $\mathrm{C}_{\text {org }}$ whose concentration increases down the section. The organic matter type in the section often varies between the humic and humic-sapropel, with the humic type III dominating. A large number of sapropel components were identified in the organic matter of the Okobykay and Lower Nutov sub-horizons.

The genetic index value indicates that the deposition was occurring in a sub-reducing environment. 
The crude oils include oleananes, which are usually found in lake deposits or marine clays and were derived from various onland precursors, especially angiosperms, which are produced by resins. Their occurrence in marine environments was most likely caused by the transport from onland sources.

Thus, the hydrocarbon parameters of the hydrocarbon attributes in the identified crude oil and condensate genotypes from the northeastern part of the Sakhalin shelf indicate that the source of their generation was the organic matter of diverse facies-genetic types. Type I crude oils were generated by the initial organic matter with a large fraction of the sapropel component; type II crude oils were generated by the initial organic matter with a large fraction of the humic component.
Based on the modeling results, 6 large independent oil and gas generation foci associated with different tectonic elements and encompassing different stratigraphic ranges are identified on the Sakhalin shelf. Each of these ranges could have independently produced hydrocarbon fluids for filling up the adjacent traps.

\section{ACKNOWLEGEMENT}

This work was supported by the Ministry of Education and Science of Russia within the framework of the Task No. 10.6569.2017 / BP for the implementation of research work (the basic part of the state task in the area of scientific activity)

\section{REFERENCES}

1. Bogoyavlensky, V.I.; Kerimov, V.Yu.; Olkhovskaya, O.O. Neftyanoe Khozyaystvo., 2016, 6, 43-47.

2. Greckaya, E.V. Nauchno-tekhnicheskij vestnik OAO NK «Rosneft»., 2012, 28, 38-42.

3. Yong-Tai Yang. Earth-Science Reviews., 2013, 126, 96-115.

4. Espitali, J.; Durand, B.; Roussel, J. C.; Souron, C. Rev. Inst. Fr. Pétr., 1973, 28, 1, 37-66.

5. Bazhenova, O.K. Geologiya i geohimiya nefti i gaza., 1990, 7, 2.

6. Gordadze, G.N.; Giruts, M.V.; Gordadze, T.I.; Rusinova, G.V. Petroleum Chemistry., 2005, 45(2) 65-71.

7. Kerimov, V.Y.; Osipov, A.V., Mustaev, R.N.; Monakova, A.S. 16th Science and Applied Research Conference on Oil and Gas Geological Exploration and Development, GEOMODEL, 2014.

8. Kerimov, V.Yu.; Lapidus, A.L.; Yandarbiev, N.Sh.; Movsumzade, E.M.; Mustaev, R.N. Solid Fuel Chemistry., 2017, 51(2), 122-130.

9. Guliev, I.S.; Kerimov, V.Yu.; Mustaev, R.N. Doklady Earth Sciences., 2016, 471(1) 1109-1112.

10. Kerimov, V.Yu.; Bondarev, A.V.; Mustaev, R.N.; Khoshtaria, V.N. Neftyanoe Khozyaystvo., 2017, 8, 36-41.

11. Kerimov, V.Yu.; Mustaev, R.N.; Bondarev, A.V. Orient. J. Chem., 2016, 32(6) 3235-3241.

12. Kerimov, V.Yu.; Mustaev, R.N.; Dmitrievsky, S.S.; Yandarbiev, N.Sh.; Kozlova, E.V. Neftyanoe Khozyaystvo., 2015, 10, 50-53.

13. Pelet, R. Rev. d'Institut Francais du Pétrole., 1985, 40(5) 551-556.

14. Peters, K.E.. AAPG Bulletin., 1986, 70(3) 318.
15. Kerimov, V.Yu.; Mustaev, R.N.; Dmitrievsky, S.S.; Zaitsev, V.A. Neftyanoe Khozyaystvo. 2016, 9, 18-21.

16. Guliyev, I.S.; Kerimov, V.Y.; Osipov, A.V.; Mustaev, R.N. SOCAR Proceedings., 2017, 1, 4-16.

17. Rachinsky, M.Z.; Kerimov, V.Yu. Fluid dynamics of oil and gas reservoirs, Scrivener Publishing Wiley., 2015, 613.

18. Kerimov, V.Yu.; Mustaev, R.N.; Serikova, U.S.; Lavrenova, E.A.; Kruglyakova, M.V. Neftyanoe Khozyaystvo., 2015, 3, 56-60.

19. Kerimov, V.Yu; Rachinsky, M.Z. Doklady Earth Sciences., 2016, 471(1) 1123-1125.

20. Mustaev, R.N. Orient. J. Chem., 2017, 33(4) 2036-2044

21. Kerimov, V.Yu.; Shilov, G.Ya.; Mustaev, R.N.; Dmitrievskiy, S.S. Neftyanoe Khozyaystvo., 2016, 2, 8-11.

22. Kerimov, V.Yu.; Osipov, A.V.; Lavrenova, E.A Neftyanoe Khozyaystvo., 2014, 4, 33-35.

23. Kerimov, V.Yu.; Mustaev, R.N.; Yandarbiev, N.Sh.; Movsumzade, E.M. Orient. J. Chem. 2017, 33(2) 879-892.

24. Mustaev, R.N.; Hai, W.N.; Kerimov, V.Y. Leonova, E.A. Geomodel 2015 - 17th Scientific-Practical Conference on Oil and Gas Geological Exploration and Development., 2015, 212-216.

25. Kerimov, V.Yu.; Rachinsky, M.Z.; Mustaev, R.N.; Osipov, A.V. Doklady Earth Sciences. 2017, 476(1) 1066-1068.

26. Vu, N.; Mustaev, R.N.; Sericova, U.S.; Leonova, E.A.; Kerimov, V.Y. Geomodel 2016 - 18th Science and Applied Research Conference on Oil and Gas Geological Exploration and Development., 2016. 